\title{
POLITIK HUKUM KEWENANGAN KONSTITUSIONAL DEWAN PERWAKILAN DAERAH DALAM PROSES LEGISLASI PASCA PUTUSAN MK NOMOR 92/PUU-X/2012
}

(Politics of Law of The Constitutional Authority of Regional Representatives Council In The Legislative Process after the Constitutional Court Decision Number 92/PUU-X/2012)

\author{
Anna Triningsih \\ MK Republik Indonesia \\ J. Medan Merdeka Barat No. 6, Jakarta Pusat 10110
}

Naskah diterima: 15 Oktober 2015; revisi: 27 November 2015; disetujui: 2 Desember 2015

\begin{abstract}
Abstrak
Undang-Undang Nomor 17 Tahun 2014 tentang Majelis Permusyawaratan Rakyat, Dewan Perwakilan Rakyat, Dewan Perwakilan Daerah, Dan Dewan Perwakilan Rakyat Daerah (UU MD3) pasca putusan Mahkamah Konstitusi (MK) dinilai memiliki problem substantif/materil akibat materi muatannya bertentangan dengan Undang-Undang Negara Republik Indonesia Tahun 1945 (UUD NRI 1945), yang mengakibatkan kerugian konstitusional terhadap Dewan Perwakilan Daerah (DPD), meliputi dikuranginya kewenangan DPD untuk dapat mengajukan (Rancangan Undang-Undang) RUU, dikuranginya kewenangan DPD untuk membahas RUU dan dikuranginya kewenangan DPD dalam kedudukannya sebagai lembaga perwakilan daerah. Hal ini menunjukan bahwa pembentukan UU MD3 nyata-nyata tidak menghormati putusan MK yang diberi mandat UUD NRI 1945 sebagai lembaga penafsir dan penjaga konstitusi, dengan tidak menghormati, mematuhi, dan melaksanakan putusan MK ini menunjukkan ketidakpatuhan terhadap putusan lembaga negara yang telah ditunjuk konstitusi untuk mengawal kemurnian pelaksanaan konstitusi. Penelitian ini menggunakan metode normatif menggunakan pendekatan perundang-undangan (statute approach), pendekatan konsep (conceptual approach), dan pendekatan historis (historical approach). Ketidaktaatan penyusunan UU MD3 pada putusan MK merupakan pengingkaran UUD NRI 1945 dan perkembangan ini merupakan langkah mundur reformasi. Pembentuk Undang-Undang, dalam hal ini, Dewan Perwakilan Rakyat (DPR) dan Presiden harus segera melakukan perubahan UU Nomor 12 Tahun 2011 tentang Pembentukan Peraturan Perundang-undangan dengan berpijak pada rambu-rambu konstitusional Putusan MK Nomor 92/PUU-X/2012.
\end{abstract}

Kata Kunci: kewenangan, Dewan Perwakilan Daerah, putusan Mahkamah Konstitusi

\begin{abstract}
Law Number 17 Year 2014 on the People's Consultative Assembly, House of Representatives, Regional Representatives Council, and the Regional House of Representatives (MD3 Law) after the decision of the Constitutional Court (MK) is considered to have a substantive problem due to the substance that is contrary to the 1945 Constitution of the Republic of Indonesia (the 1945 Constitution), which resulted in the constitutional loss of Regional Representatives Council (DPD), including the reduction of DPD authority to propose draft bills, to discuss draft bills and the reduction in its authority as the regional representative institution. This shows that the drafting of MD3 Law is obviously not respecting the decision of the Court that is mandated by the 1945 Constitution as the interpreter and guardian institution of the constitutional, by not respecting, obeying and implementing $M K$ 's decision which indicates non-compliance with the decision of the state institution that has been designated to guard the purity of the constitution implementation of the constitution. This study uses normative method with statute approach, conceptual approach and a historical approach. The noncompliance of the drafting of MD3 Law towards the MK's decision is a denial of MK and this development is a step back of Reformation. The legislators, in this case, the House of Representatives (DPR) and the President should immediately amend the Law Number 12 Year 2011 on the Establishment of Laws and Regulations based on the MK's Decision No. 92/PUU-X/2012.
\end{abstract}

Keywords: authority, Regional Representatives Council, Constitutional Court Decision 


\section{A. Pendahuluan}

Setelah perubahan Undang-Undang Dasar Negara Republik Indonesia Tahun 1945 (UUD NRI 1945), fungsi legislasi dalam arti sempit (membentuk Undang-Undang) dimiliki Dewan Perwakilan Rakyat (DPR) dan Dewan Perwakilan Daerah (DPD). Sistem bikameral dalam pembentukan Undang-Undang ini mengatur kewenangan yang seimbang antara DPR dan DPD. DPD merupakan lembaga negara yang memiliki kedudukan yang sama dengan DPR sebagai lembaga perwakilan rakyat. ${ }^{1}$ DPD juga merupakan lembaga perwakilan daerah yang berkedudukan sebagai lembaga negara yang terdiri dari wakil-wakil daerah provinsi yang dipilih melalui pemilihan umum tanpa melibatkan peranan partai politik.

Pembentukan DPD sebagai salah satu institusi negara yang baru bertujuan memberikan kesempatan kepada orang-orang daerah untuk ikut mengambil kebijakan dalam tingkat nasional, khususnya yang terkait dengan kepentingan daerah. ${ }^{2}$ Berdasarkan ketentuan Pasal 22D ayat (1) dan ayat (2) UUD NRI 1945, DPD memiliki kewenangan dalam hal prakarsa pembuatan Undang-Undang dan pembahasan Rancangan Undang-Undang, walaupun terdapat pembahasan Rancangan Undang-Undang. Keberadaan DPD dalam sistem ketatanegaraan Indonesia tidak dapat dilepaskan dari pelembagaan fungsi representasi. Dalam rangka pelembagaan fungsi representasi itu, dikenal adanya 3 (tiga) sistem perwakilan yang dipraktekkan diberbagai negara demokrasi yaitu: a. sistem perwakilan politik (political representative);

b. sistem perwakilan teritorial (teritorial representative); dan

c. sistem perwakilan fungsional (fungsional representative). ${ }^{3}$

Pengaturan lebih lanjut mengenai kewenangan DPD tersebut diatur dalam UndangUndang Nomor 27 Tahun 2009 tentang Majelis Permusyawaratan Rakyat, Dewan Perwakilan Rakyat, Dewan Perwakilan Daerah, dan Dewan Perwakilan Rakyat Daerah (UU 27/2009) dan Undang-Undang Nomor 12 Tahun 2011 tentang Pembentukan Peraturan Perundang-undangan (UU P3).

DPD dalam kurun waktu Oktober 2004 sampai dengan Oktober 2014 telah mengajukan 57 (lima puluh tujuh) RUU, 237 (dua ratus tiga puluh tujuh) Pandangan dan Pendapat, 74 (tujuh puluh empat) Pertimbangan dan 138 (seratus tiga puluh delapan) hasil pengawasan. Seluruh RUU tersebut telah disampaikan kepada DPR namun tidak semua ada tindak lanjutnya. Beberapa RUU tersebut telah menjadi undangundang namun bukan merupakan merupakan RUU usul inisiatif DPD dan keterlibatan DPD dalam pembahasan RUU tersebut sangat terbatas, hanya RUU Kelautan yang menjadi usul inisiatif DPD dan akhirnya menjadi undangUndang yang pembahasannya dilakukan secara 3 (tiga) pihak (tripatrit) yaitu: DPR, Pemerintah dan DPD. ${ }^{4}$

Dalam rangka mendudukan fungsi legislasi DPD sesuai dengan UUD NRI 1945, pada tanggal 
14 September 2012, DPD telah menyampaikan permohonan Pengujian Undang-Undang atas UU 27/2009 dan UU P3 terhadap UUD NRI 1945 kepada Mahkamah Konstitusi (MK) yang kemudian diregistrasi dalam nomor perkara 92/ PUU-X/012. Permohonan uji materi dimaksud, dilakukan untuk memperoleh penafsiran yang lebih tepat dan pasti bagi kepentingan bersama dalam sistem legislasi antara DPR, DPD, dan Presiden. Melalui beberapa kali sidang, akhirnya pada hari Rabu, tanggal 27 Maret 2013, pukul 15.20 WIB, MK memutus perkara tersebut, yang dimuat dalam Berita Negara Republik Indonesia Nomor 26 Tahun 2013. Dalam putusannya itu, MK telah menegaskan 5 (lima) hal keterlibatan DPD dalam proses legislasi ${ }^{5}$, yaitu:

a. dalam mengajukan RUU yang berkaitan dengan daerah, DPD setara dengan DPR dan Presiden;

b. Hak/kewenangan DPD sama dengan DPR dan Presiden dalam membahas RUU;

c. DPD ikut membahas RUU tetapi tidak ikut memberi persetujuan terhadap RUU menjadi UU;

d. DPD ikut menyusun Program Legislasi Nasional; dan

e. DPD memberikan pertimbangan tanpa ikut serta dalam pembahasan RUU. Dalam hal ini, DPR dan Presiden wajib untuk meminta pertimbangan DPD atas RUU APBN.

Dalam putusan tersebut MK dengan tegas menyatakan bahwa Pasal 102 ayat (1) huruf a, huruf $d$, huruf e, dan huruf $h$, serta Pasal 147 UU 27/2009 bertentangan dengan UUD NRI 1945 dan tidak mempunyai kekuatan hukum mengikat. Hal tersebut berarti setiap RUU yang diajukan oleh DPD tidak lagi melalui proses di
Badan Legislasi melainkan diperlakukan setara dengan RUU yang diajukan oleh Presiden dan harus tetap dianggap sebagai RUU yang diajukan oleh DPD. Putusan ini dipandang mengembalikan jati diri DPD sebagai lembaga negara yang dalam legislasi kedudukannya setara dengan DPR dan Presiden.

Seirama dengan putusan tersebut, Pasal 18 huruf (g), Pasal 20 ayat (1), Pasal 21 ayat (1), Pasal 22 ayat (1), Pasal 23 ayat (2), dan Pasal 43 ayat (1) UU P3 dinyatakan dianggap berlaku dan memiliki kekuatan hukum mengikat sepanjang ditambahkan frasa "DPD", yang artinya mengakui keberadaan DPD sebagai lembaga negara yang memiliki hak dan kedudukan yang sama dengan lembaga negara lainnya yaitu DPR dan Presiden untuk mengajukan RUU. Pasal 143 ayat (5) UU 27/2009 juga dianggap dinyatakan berlaku dan memiliki kekuatan hukum mengikat sepanjang ditambahkan frasa, “...kepada pimpinan DPD untuk RUU yang berkaitan dengan otonomi daerah, hubungan pusat dan daerah, pembentukan dan pemekaran serta penggabungan daerah, pengelolaan sumber daya alam dan sumber daya ekonomi lainnya, serta perimbangan keuangan pusat dan daerah." Hal serupa berlaku pula terhadap Pasal 144 UU 27/2009 dimana pasal ini dianggap berlaku dan memiliki kekuatan hukum mengikat sepanjang ditambahkan frasa, “... dan kepada pimpinan DPD untuk RUU yang berkaitan dengan otonomi daerah, hubungan pusat dan daerah, pembentukan dan pemekaran serta penggabungan daerah, pengelolaan sumber daya alam dan sumber daya ekonomi lainnya, serta perimbangan keuangan pusat dan daerah."

Putusan MKNomor 92/PUU-X/2012. 
Dalam amarnya, Putusan MK Nomor 92/ PUU-X/2012 menyebutkan pula bahwa Pasal 150 ayat (3) UU 27/2009 berlaku dan memiliki kekuatan hukum mengikat sepanjang dimaknai "DPD mengajukan Daftar Isian Masalah (DIM) atas RUU yang berasal dari Presiden atau $D P R$ yang berkaitan dengan otonomi daerah, hubungan pusat dan daerah, pembentukan dan pemekaran serta penggabungan daerah, pengelolaan sumber daya alam dan sumber daya ekonomi lainnya, serta perimbangan keuangan pusat dan daerah." Berdasarkan amar tersebut dapat disimpulkan bahwa DPD berwenang untuk terlibat dan membahas RUU mulai dari tahap pengantar musyawarah, tahap pengajuan dan pembahasan DIM, dan tahap pendapat mini. Putusan MK ini juga berlaku bagi pasal-pasal dalam UU P3 yang pengaturannya satu nafas dengan pasal-pasal dalam UU 27/2009 yang dianulir MK tersebut.

Putusan tersebut disambut gembira, terutama oleh DPD yang dalam proses legislasi selama ini dianggap sekedar menjadi bayangbayang karena didudukkan inferior berada di bawah dominasi DPR. ${ }^{6}$ Inferioritas DPD dalam proses legislasi telah sejak lama menjadi sorotan, bahkan sejak awal-awal keberadaan DPD sendiri. Inferioritas DPD tersebut dianggap sebagai anomali dalam sistem bikameral sebagaimanayang dipraktikkan di banyaknegara. Menyebut lemah dan tidak imbangnya posisi DPD dibandingkan DPR dalam proses legislasi tersebut, M. Fajrul Falakh menggolongkannya ke dalam asymetric bicameralism. Menurut Giovanni Sartori, asymmetric bicameralism atau weak bicameralism atau soft bicameralism menunjuk pada kondisi apabila kekuatan salah satu kamar jauh lebih dominan atas kamar lainnya. ${ }^{7}$

Menurut sejarahnya, DPD dihadirkan dalam ketatanegaraan Indonesia untuk menciptakan sistem checks and balances yang baik dalam proses legislasi. Sebagai representasi rakyat daerah, DPD seharusnya memiliki posisi yang penting dalam pengambilan kebijakan negara melalui legislasi. Namun dalam kenyataannya, DPD tidak diberikan peran signifikan sebagaimana mestinya dalam proses legislasi. Menurut Stephen Sherlock, DPD merupakan contoh tidak lazim dalam praktik lembaga perwakilan rakyat dengan sistem bikameral karena merupakan kombinasi dari lembaga dengan kewenangan yang amat terbatas dan legitimasi tinggi (represents the odd combination of limited powers and high legitimacy). ${ }^{8}$

Berdasarkan ketentuan Pasal 24C ayat (1) UUD NRI $1945^{9}$ yang menyatakan bahwa putusan MK bersifat final. Hal ini berarti putusan MK telah 
memiliki kekuatan hukum tetap dan memiliki kekuatan hukum mengikat untuk dilaksanakan oleh semua orang, Lembaga Negara dan badan hukum dalam yurisdiksi Indonesia. Pada tanggal 8 Juli 2014, rapat paripurna DPR mengesahkan RUU perubahan UU No 27 Tahun 2009 tentang MPR, DPD, dan DPRD menjadi UU MD3. Materi ayat, pasal dan/atau bagian dari UU MD3 tersebut tidak sesuai dengan UUD NRI 1945 dan Putusan MK yang menyangkut kedudukan DPD. Ketidaktaatan penyusunan UU MD3 pada putusan MK merupakan pengingkaran UUD NRI 1945 dan perkembangan ini merupakan langkah mundur reformasi.

\section{B. Metode Penelitian}

Penelitian ini merupakan penelitian terhadap Putusan MK Nomor 92/PUU-X/2012 dengan menggunakan metode normatif. Penelitian hukum normatif mendasarkan pada hukum sebagai sebuah bangunan sistem norma. Norma dalam hal ini mengenai asas-asas, norma, kaidah dari peraturan perundangan, putusan pengadilan, perjanjian serta doktrin (ajaran). ${ }^{10}$ Penelitian ini menggunakan pendekatan perundang-undangan (statute approach), pendekatan konsep (conceptual approach), dan pendekatan historis (historical approach). ${ }^{11}$ Pendekatan perundang-undangan dilakukan dengan menelaah berbagai peraturan perundang-undangan dan peraturan lainnya yang mengatur tentang kewajiban untuk menaati Putusan MK. Pendekatan konsep dilakukan mulai dari mendalami konsep negara hukum, konsep kedaulatan rakyat. Pendekatan historis dilakukan dengan cara meneliti latar belakang dan argumentasi hukum MK dalam Putusan MK Nomor 92/PUU-X/2012 dan materi kewenangan DPD yang tertuang dalam UU MD3.

Dalam penelitian hukum normatif, pengolahan data pada hakikatnya merupakan kegiatan untuk mensistematisasi bahan hukum. Sistematisasi berarti membuat klasifikasi terhadap bahan-bahan hukum tersebut untuk memudahkan pekerjaan analisis dan konstruksi. ${ }^{12}$ Analisis bahan hukum dilakukan melalui tiga tahapan. Pertama, bahan hukum atau fakta yang dikumpulkan disistematisir yakni ditata dan disesuaikan dengan obyek yang diteliti. Kedua, bahan yang telah disistematisir dieksplikasi atau diuraikan dan dijelaskan sesuai obyek yang diteliti berdasarkan teori. Ketiga, bahan yang telah dieksplikasi dilakukan evaluasi, dinilai dengan menggunakan ukuran ketentuan hukum yang berlaku sehingga ditemukan ada yang sesuai dan ada tidak sesuai (bertentangan) dengan hukum yang berlaku. ${ }^{13}$

\section{Pembahasan}

\section{Teori Negara Hukum}

Istilah konstitusi telah lama dikenal sejak zaman Yunani Kuno, diduga konstitusi Athena yang ditulis oleh Xenophon (abad 425 SM) merupakan konstitusi pertama dipandang

\footnotetext{
10 Mukti Fajar dan Yulianto Achmad, Dualisme Penelitian Hukum Normatif dan Empiris, (Yogyakarta: Pustaka Pelajar, 2010), hlm. 34.

11 Johny Ibrahim, Teori dan Metodologi Penelitian Hukum Normatif, (Malang: Bayumedia, 2005), hlm. 302.

12 Sebagaimana dikutip oleh Soerjono Soekanto, Pengantar Penelitian Hukum, (Jakarta: UI Press, 1986), hlm. 251252.

13 Abdul Latif, Fungsi MKdalam Mewujudkan Negara Hukum Demokrasi, (Yogyakarta: Total Media, 2007 ), hlm. 61.
} 
sebagai alat demokrasi yang sempurna. Dapat diduga bahwa pemahaman orang tentang apa yang diartikan konstitusi, sejalan dengan pemikiran orang-orang Yunani Kuno tentang negara. Hal ini dapat diketahui dari paham Socrates yang kemudian dikembangkan oleh muridnya Plato, dalam bukunya politea atau negara, yang memuat ajaran-ajaran Plato tentang negara atau hukum, dan bukunya Nomoi atau undang-undang dan juga tulisan Aristoteles dalam bukunya politica yang membicarakan tentang negara hukum atau negara (keadilan). ${ }^{14}$

Ide negara hukum, selain terkait dengan konsep rechtsstaats dan the rule of law, juga berkaitan dengan konsep nomocracy yang berasal dari kata nomos dan cratos. Kata nomokrasi dapat dibandingkan dengan demos dan cratos aau kratein dalam demokrasi. Nomos berarti norma, sedangkan cratos adalah kekuasaan. Faktor penentu dalam kekuasaan adalah norma atau hukum. Karena itu istilah nomokrasi itu berkaitan erat dengan ide keadulatan hukum atau prinsip hukum sebagai kekuasaan tertinggi. Dalam istilah yang dikembangkan A.V. Dicey, hal itu dapat dikaitkan dengan prinsip "rule of law" yang dikembangkan di Amerika Serikat menjadi jargon "the rule of law, and not of man". Sesungguhnya yang dianggap sebagai pemimpin adalah hukum itu sendiri, bukan orang. ${ }^{15}$

Menurut Julius Stahl, konsep negara hukum yang disebutnya dengan istilah rechtsstaats ini mencakup 4 (empat) elemen penting yaitu: 1) perlindungan hak asasi manusia; 2) pembagian kekuasaan; 3) pemerintahan berdasarkan undang-undang; dan 4) peradilan tata usaha negara. ${ }^{16}$ A.V. Dicey menguraikan ada 3 (tiga) ciri penting dalam negara yang disebut dengan istilah "the rule of law" yaitu: 1) supremacy of law; 2) equality before the law; dan 3) due process of law. ${ }^{17}$ Memasuki abad XX, konsep negara hukum mengalami perkembangan yang menginginkan kehidupan yang lebih demokrasi. Menurut Scheltema, ada 4 (empat) unsur negara hukum yaitu: 1) adanya kepastian hukum; 2) asas persamaan; 3) asas demokrasi; dan 4) asas pemerintahan untuk rakyat. ${ }^{18}$

Perubahan UUD NRI 1945 mengenai penyelenggaraan kekuasaan negara dilakukan dengan mempertegas kekuasaan dan wewenang lembaga negara berdasarkan fungsi penyelenggaraan negara yang dibangun dalam sistem hubungan checks and balances. Perubahan tersebut membawa implikasi konstitusional yang mendalam yang tercermin pada sistem penyelenggaraan kekuasaan negara setelah perubahan. Jika kedaulatan rakyat sebelum perubahan dilakukan sepenuhnya oleh MPR, maka setelah perubahan kedaulatan rakyat dilaksanakan menurut UUD NRI 1945 yang didalamnya diatur mekanisme penyelenggaraan kedaulatan rakyat sesuai dengan fungsi dan kewenangannya. Dalam hal ini DPR, DPD dan Presiden menyelenggarakan kedaulatan rakyat 
dibidang legislasi sesuai dengan ketentuan UUD NRI 1945.

\section{Teori Kedaulatan Rakyat}

Menurut J Jacques Rousseau, konsep kedaulatan bersifat kerakyatan dan didasarkan pada kemauan umum (volunte generale) rakyat yang menjelma melalui perundangundangan. Oleh sebab itu, menurutnya, konsep kedaulatan mempunyai sifat-sifat yaitu ${ }^{19}:$ 1) kesatuan (unite), bersifat monistis; 2) bulat dan tidak berbagi (individisibilite); 3) tidak dapat dialihkan (inalienabilite); dan 4) tidak dapat berubah (imprescriptibilite). Teori ini juga diikuti oleh Immanuel Kant, mengatakan bahwa tujuan negara itu adalah menegakkan hukum dan menjamin kebebasan daripada para warga negaranya.Dalam hal pengertian bahwa kebebasaan-kebebasan disini adalah kebebasan dalam batas-batas perundang-undangan, sedangkan undang-undang disini yang berhak membuat adalah masyarakat itu sendiri. Dengan demikian, undang-undang merupakan penjelmaan dari pada kemauan atau kehendak rakyat. Jadi rakyatlah yang mewakilikekuasaan tertinggi atau kedaulatan. ${ }^{20}$

Indonesia adalah satu negara yang menjadikan demokrasi sebagai aturan dasarnya. Sesuai dengan Pasal 1 ayat (2) UUD NRI 1945, dengan ketentuan tersebut dapat diartikan bahwa pemilik kedaulatan dalam negara Indonesia adalah rakyat, pelaksanaan kedaulatan ditentukan menurut UUD NRI 1945. ${ }^{21}$ Pelaksanaan kedaulatan negara Indonesia menurut UUD NRI 1945 adalah rakyat dan lembaga-lembaga negara yang berfungsi menjalankan tugas-tugas kenegaraan sebagai representasi kedaulatan rakyat. UUD NRI 1945 menentukan, bahwa rakyat dapat secara langsung melaksanakan kedaulatan yang dimilikinya. Keterlibatan rakyat sebagai pelaksana kedaulatan di dalam UUD NRI 1945 ditentukan dalam hal:

a. Mengisi keanggotaan MPR, karena anggota MPR terdiri dari anggota DPR dan anggota DPD yang terpilih melalui pemilihan umum, sebagaimana dinyatakan dalam Pasal 2 ayat (1).

b. Mengisi keanggotaan DPR melalu pemilihan umum, sebagaimana dinyatakan dalam Pasal 19 ayat (1).

c. Mengisi keanggotaan DPD, sebagaimana dinyatakan dalam Pasal 22C ayat (1).

d. Memilih Presiden dan Wakil Presiden dalam satu pasangan secara langsung, sebagaimana dinyatakan dalam Pasal 6A ayat (1).

UUD NRI 1945 menentukan secara tegas bahwa anggota DPD dipilih dari setiap provinsi melalui pemilihan umum, ${ }^{22}$ yang jumlahnya sama untuk setiap provinsi serta seluruh anggota DPD tidak lebih dari sepertiga anggota DPR. ${ }^{23}$ Penegasan jumlah wakil yang sama dari

19 Jimly Asshiddiqie, Op. Cit, 2006, hlm. 152.

20 Moh. Mahfud MD, Dasar dan Struktur Kenegaraan Indonesia, Cetakan Kedua, (Jakarta: Rineka Cipta, 2001), hlm. 104.

21 Indonesia, Undang-Undang Dasar Negara Republik Indonesia Tahun 1945, Pasal 1 ayat (2): "Kedaulatan berada di tangan rakyat dan dilaksanakan menurut Undang-Undang Dasar".

22 Indonesia, Undang-Undang Dasar Negara Republik Indonesia Tahun 1945, Pasal 22C ayat (1) "Anggota Dewan Perwakilan Daerah dipilih dari setiap provinsi melalui pemilihan umum".

23 Indonesia, Undang-Undang Dasar Negara Republik Indonesia Tahun 1945, Pasal 22C ayat (2) "Anggota Dewan Perwakilan Daerah dari setiap provinsi jumlahnya sama dan jumlah seluruh anggota Dewan Perwakilan Daerah itu tidak lebih dari sepertiga jumlah anggota Dewan Perwakilan Rakyat". 
setiap provinsi mengandung maksud bahwa setiap provinsi di Indonesia diperlakukan sama menurut UUD NRI 1945, sekecil apapun daerah provinsi itu merupakan bagian dari wilayah Indonesia yang menjadikan Indonesia bersatu. Anggota DPD tidak lebih dari sepertiga anggota DPR, dimaksudkan agar ada perimbangan keanggotaan MPR yang terdiri dari anggota DPR dan anggota DPD.

\section{Tugas dan Fungsi DPD dalam Sistem Ketatanegaraan}

DPD sebagai lembaga perwakilan rakyat dari daerah yang ada di pusat dalam menyalurkan aspirasi rakyat harus memiliki fungsi yang jelas. Menurut Jimly Asshiddiqie, fungsi parlemen dapat dibedakan menjadi 3 (tiga) macam, yaitu fungsi pengaturan (legislasi), fungsi pengawasan (kontrol), fungsi perwakilan dan representasi. ${ }^{24}$ Pengaturan mengenai fungsi DPD ini dijabarkan dalam Pasal 22D UUD NRI 1945 yang menyebutkan bahwa:

(1) Dewan Perwakilan Daerah dapatmengajukan kepada Dewan Perwakilan Rakyat rancangan undang-undang yang berkaitan dengan otonomi daerah, hubungan pusat dan daerah, pembentukan dan pemekaran serta penggabungan daerah, pengelolaa sumber daya alam dan sumber daya ekonomi lainnya, serta yang berkaitan dengan perimbangan keuangan pusat dan daerah.

(2) Dewan Perwakilan Daerah ikut membahas rancangan undang-undangan yang berkaitan dengan otonomi daerah; hubungan pusat dan daerah; pembentukan, pemekaran, dan penggabungan daerah; pengelolaan sumber

daya alam dan sumber daya ekonomi lainnya, serta perimbangan keuangan pusat dan daerah; serta memberikan pertimbangan kepada Dewan Perwakilan Rakyat atas rancangan undang-undang anggaran pendapatan dan belanja negara dan rancangan undang-undang yang berkaitan dengan pajak, pendidikan, dan agama.

(3) Dewan Perwakilan Daerah dapat melakukan pengawasan atas pelaksanaan undang-undang mengenai; otonomi daerah, pembentukan, pemekaran dan penggabungan daerah, hubungan pusat dan daerah, pengelolaan sumber daya alam dan sumber daya ekonomi lainnya, pelaksanaan anggaran pendapatan dan belanja negara, pajak, pendidikan, dan agama serta menyampaikan hasil pengawasannya itu kepada Dewan Perwakilan Rakyat sebagai bahan pertimbangan untuk ditindaklanjuti.

Pengaturan fungsi DPD ini pun dijabarkan dalam Pasal 223 ayat (1) UU 27/2009, yang mengatur bahwa DPD mempunyai fungsi:

a. pengajuan usul kepada DPR mengenai rancangan undang-undang yang berkaitan dengan otonomi daerah, hubungan pusat dan daerah, pembentukan dan pemekaran serta penggabungan daerah, pengelolaan sumber daya alam dan sumber daya ekonomi lainnya, serta yang berkaitan dengan perimbangan keuangan pusat dan daerah;

b. ikut dalam pembahasan rancangan undang-undang yang berkaitan dengan otonomi daerah, hubungan pusat dan daerah, pembentukan, pemekaran dan

24 Jimly Asshiddiqie, Pokok-Pokok Hukum Tata Negara Indonesia Pasca Reformasi, Jakarta: Bhuana Ilmu Populer, 2007), hlm.160. 
penggabungan daerah, pengelolaan sumber daya alam dan sumber daya ekonomi lainnya, serta perimbangan keuangan pusat dan daerah;

c. pemberian pertimbangan kepada DPR atas rancangan undang-undang tentang anggaran pendapatan dan belanja negara dan rancangan undang-undang yang berkaitan dengan pajak, pendidikan, dan agama; dan

d. pengawasan atas pelaksanaan undangundang mengenai otonomi daerah, pembentukan, pemekaran dan penggabungan daerah, hubungan pusat dan daerah, pengelolaan sumber daya alam dan sumber daya ekonomi lainnya, pelaksanaan APBN, pajak, pendidikan, dan agama.

Kewenangan DPD dalam Pasal 22D ayat (1) UUD NRI 1945, dibatasi hanya dapat mengajukan rancangan undang-undang tertentu kepada DPR, DPD tidak memiliki kewenangan membahas sampai dengan memutuskan suatu rancangan undang-undang, bahkan yang terkait langsung dengan daerah, sehingga DPD tidak dapat secara optimal mengawal aspirasi masyarakat dan daerah dalam pembentukan legislasi nasional. ${ }^{25}$ Pengawasan atas pelaksanaan undang-undang yang dilakukan DPD sebagaimana ketentuan Pasal 22D ayat (3) tidak efektif karena hasil pengawasan DPD tidak secara langsung disampaikan kepada pemerintah tetapi disampaikan kepada DPR sebagai bahan pertimbangan. ${ }^{26}$ Terkait fungsi pertimbangan (konsultasi) DPD mempunyai tugas dan wewenang untuk memberikan pertimbangan kepada DPR terkait RUU APBN, RUU berkaitan dengan pajak, pendidikanm dan agama dan pemilihan anggota Badan Pemeriksa Keuangan (BPK). Dalam hal pengawasan, tugas dan fungsi DPD pengawasan atas pelaksanaan undang-undang dan menyampaikan hasil pengawasannya kepada DPR sebagai pertimbangan untuk ditindak lanjuti terkait dengan bidang otonomi daerah, pembentukan dan pemekaran serta penggabungan daerah, pengelolaan sumber daya alam dan sumber daya ekonomi lainnya, perimbangan keuangan pusat dan daerah, pelaksanaan APBN, pajak, pendidika dan agama dan menerima hasil pemeriksaan keuangan negara yang dilakukan BPK. Mengenai fungsi anggaran, merupakan fungsi khusus yang dirangkum ketiga fungsi diatas terkait masalah keuangan dan anggaran. Mempunyai tugas dan wewenang dapat mengajukan RUU tentang perimbangan keuangan pusat dan daerah (legislasi), memberikan perimbangan terhadap RUU APBN (konsultasi), melakukan pengawasan terhadap pelaksanaan APBN (kontrol), perimbangan keuangan pusat dan daerah, terkait RUU APBN, serta pelaksanaan APBN.

\section{Politik Hukum Kewenangan Legislasi DPD Pasca Putusan MK Nomor 92/ PUU-X/2012}

Legal policy atau garis (kebijakan) resmi tentang hukum yang akan diberlakukan baik dengan pembuatan hukum baru maupun dengan penggantian hukum lama, dalam rangka mencapai tujuan negara. Dengan

\footnotetext{
25 Kelompok DPD di MPR RI, Eksistensi DPD RI 2009-2013 Untuk Daerah dan NKRI, Cetakan Kedua, (Jakarta: Kelompok DPD di MPR RI, 2013), hlm. 53.

26 Ibid, hlm. 54.
} 
demikian, politik hukum merupakan pilihan tentang hukum-hukum yang akan diberlakukan sekaligus pilihan tentang hukum-hukum yang akan dicabut atau tidak diberlakukan sekaligus pilihan tentang hukum-hukum yang akan dicabut atau tidak diberlakukan yang kesemuanya dimaksudkan untuk mencapai tujuan negara seperti yang tercantum di dalam pembukaan UUD NRI 1945. ${ }^{27}$

Pendapat Mahkamah yang dituangkan dalam putusan MK Nomor 92/PUU-X/2012 bahwa Mahkamah menyatakan seluruh ketentuan UU 27/2009 dan UU P3 yang telah mereduksi atau mengurangi kewenangan DPD yang ditentukan oleh UUD NRI 1945 atau telah mengurangi fungsi, tugas, dan kewenangan DPD sebagaimana yang telah dikehendaki oleh konstitusi dan sebagaimana dimaksudkan pada saat DPD dibentuk dan diadakan dalam konstitusi haruslah dinyatakan inkonstitusional dan diposisikan sebagaimana mestinya sesuai dengan UUD NRI 1945. Seluruh ketentuan yang mereduksi atau mengurangi kewenangan DPD dalam kedua undang-undang tersebut, yang berkaitan dengan kewenagan DPD harus dinyatakan bertentangan dengan UndangUndang dan dinyatakan bertentangan secara bersyarat dengan UUD NRI 1945 apabila tidak sesuai dengan pemahaman atau penafsiran yang diberikan oleh MK. Terhadap penjelasan umum dan penjelasan pasal-demi pasal kedua undang-undang tersebut yang berkaitan dengan kewenangan DPD, harus pula dianggap menyesuaikan dengan pemahaman atau penafsiran yang diberikan oleh mahkamah. ${ }^{28}$ UU MD3 yang dibentuk pasca putusan MK sebagai implementasi dari putusan tersebut, tetap saja memuat ketentuan pasal-pasal yang mereduksi, bahkan mengikis kewenangan konstitusional sebagaimana telah ditegaskan oleh MK. Tidak menghormati, mematuhi dan melaksanakan putusan MK yang bersifat erga omnes berarti menunjukkan ketidakpatuhan terhadap konstitusi itu sendiri.

Secara umum substansi UU MD3 yang mengatur aspek kelembagaan antara DPR dan DPD sangat timpang, padahal dalam sistematika UUD NRI 1945 kedua lembaga ini adalah lembaga negara yang dipergunakan untuk mengimplementasikan checks and balances dalam paradigma demokrasidesentralistik. Demokrasi desentralistik adalah konsep partisipasi atau keikutsertaan daerah (teritorial) dalam perumusan kebijakan publik ditingkat nasional. UU MD3 pasca putusan MK dinilai memiliki problem substantif/ materil akibat materi muatannya bertentangan dengan UUD NRI 1945 yang mengakibatkan kerugian konstitusional terhadap DPD, meliputi dikuranginya kewenangan DPD untuk dapat mengajukan RUU, dikuranginya kewenangan DPD untuk membahas RUU dan dikuranginya kewenangan DPD dalam kedudukannya sebagai lembaga perwakilan daerah.

\section{a. Dikuranginya Kewenangan DPD Untuk Dapat Mengajukan RUU}

Kewenangan DPD untuk dapat mengajukan RUU sebagaimana dimaksud dalam Pasal 22D ayat (1) UUD NRI 1945 telah direduksi atau dirugikan oleh ketentuan-ketentuan dalam UU MD3 yaitu Pasal 166 ayat (2), Pasal 167

Moh. Mahfud MD, Politik Hukum di Indonesia, (Jakarta: Rajawali Press, 2011), hlm. 1.

28 Indonesia, Putusan MKNomor 92/PUU-X/2012. 
ayat (1), Pasal 276 ayat (1), dan Pasal 277 ayat (1), untuk dapat mengajukan kepada DPR RUU yang berkaitan dengan otonomi daerah, hubungan pusat dan daerah, pembentukan dan pemekaran serta penggabungan daerah, pengelolaan sumber daya alam dan sumber daya ekonomi lainnya, serta berkaitan dengan perimbangan keuangan pusat dan daerah, hal ini dikarenakan Pasal 166 ayat $(2)^{29}$ dan Pasal 167 ayat $(1)^{30}$ UU MD3. Ketentuan-ketentuan tersebut mengakibatkan pemasungan konstitusional terhadap DPD karena RUU yang diajukan DPD difilter oleh pimpinan DPR untuk disampaikan kepada Presiden mengingat tidak ada norma yang memerintahkan DPD untuk menyampaikan RUU beserta naskah akademik kepada Presiden.

Dalam Pasal 276 ayat (1) UU MD3, ketentuan ini mereduksi wewenang DPD karena menyebabkan DPD hanya dapat mengajukan RUU yang ada dalam Prolegnas. Padahal Pasal 22D ayat (1) UUD NRI 1945 yang ditafsirkan MK melalui putusannya bahwa DPD dapat mengajukan RUU berdasarkan pada daftar kumulatif terbuka:

"dalam keadaan tertentu, DPR, DPD, atau Presiden dapat mengajukan RUU diluar Prolegnas mencakup:

1) Untuk mengatasi keadaan luar biasa, keadaan konflik atau bencana alam; dan

2) Keadaan tertentu lainnya yang memastikan adanya urgensi nasional atas suatu RUU yang dapat disetujui bersama oleh alat kelengkapan DPR yang khusus menangani bidang legislasi dan materi yang menyelenggarakan urusan pemerintahan dibidang hukum".

Pasal 277 ayat (1) $)^{31}$ UU MD3, dalam pasal ini, surat kepada Presiden hanya bersifat tembusan, padahal berdasarkan putusan MK Nomor 92/ PUU-X/2012 butir $1.17 .5^{32}$ dan butir 1.18.14 ${ }^{33}$, yang artinya MK telah mendudukan kedudukan DPR dan Presiden dalam RUU dari DPD adalah setara. Kerugian kewenangan yang diderita DPD terkait dengan surat yang bersifat tembusan tersebut adalah terkuranginya kedudukan kesetaraan DPD dengan DPR dan Presiden dalam pengajuan RUU. Pasal 277 ayat (2) tersebut sangat berbeda bila dibandingkan dengan Pasal 278 ayat $(2)^{34}$ UU MD3, walaupun sama-sama disampaikan kepada Presiden yang bukan merupakan tembusan tetapi surat langsung.

29 Indonesia, Undang-Undang Nomor 17 Tahun 2014 tentang MD3, Pasal 166 ayat (2) "Rancangan Undang-Undang sebagaimana dimaksud pada ayat (1) beserta naskah akademik disampaikan secara tertulis oleh pimpinan DPD kepada pimpinan DPR".

30 Indonesia, Undang-Undang Nomor 17 Tahun 2014 tentang MD3, Pasal 167 ayat (1) "Rancangan Undang-Undang beserta naskah akademik yang berasal dari DPD disampaikan secara tertulis oleh pimpinan DPD kepada pimpinan $D P R^{\prime \prime}$.

31 Indonesia, Undang-Undang Nomor 17 Tahun 2014 tentang MD3, Pasal 277 ayat (1) "Rancangan Undang-Undang sebagaimana dimaksud dalam Pasal 248 ayat (3) beserta naskah akademik disampaikan dengan surat pengantar pimpinan DPD kepada pimpinan DPR dengan tembusan kepada Presiden".

32 Indonesia, Putusan MK Nomor 92/PUU-X/2012 butir 1.17.5 halaman 254 "Rancangan Undang-Undang beserta penjelasan atau keterangan dan/atau naskah akademik yang berasal dari DPD disampaikan secara tertulis oleh pimpinan DPD kepada pimpinan DPR dan kepada Presiden dan harys disertai naskah akademik".

33 Indonesia, Putusan MK Nomor 92/PUU-X/2012 butir 1.18.14 halaman 258 "Rancangan Undang-Undang dari DPD disampaikan secara tertulis oleh pimpinan DPD kepada pimpinan DPR dan kepada Presiden dan harus disertai naskah akademik".

34 Indonesia, Undang-Undang Nomor 17 Tahun 2014 tentang MD3, Pasal 278 ayat (2) "Daftar inventarisasi masalah sebagaimana dimaksud pada ayat (1) disampaikan kepada DPR dan Presiden dengan surat pengantar pimpinan $D P D^{\prime \prime}$. 


\section{b. Dikuranginya Kewenangan DPD Untuk Ikut Membahas RUU}

Untuk kewenangan ini, sebagaimana dimaksud dalam Pasal 22D ayat (2) UUD NRI 1945 direduksi/dirugikan oleh ketentuanketentuan dalam Pasal 71 huruf c, Pasal 165, Pasal 166, Pasal 170 ayat (5), Pasal 171 ayat (1) dan Pasal 249 huruf b. UU MD3 telah mengurangi kewenangan DPD yang terkait untuk ikut membahas RUU yang berkaitan dengan otonomi daerah, hubungan pusat dan daerah, pembentukan dan pemekaran serta penggabungan daerah, pengelolaan sumber daya adalam dan sumber daya ekonomi lainnya. Hal ini tertuang dalam Pasal 71 huruf $\mathrm{C}^{35}$, dimana DPD dirugikan dengan adanya ketentuan tersebut. Ketentuan tersebut hanya mengatur dalam hal RUU dari Presiden dan DPR. Untuk RUU yang diajukan DPD tidak ada pengaturannya dalam Pasal 71.

Pasal 165 dan Pasal 166 UU MD3 hanya mengatur penyampaian RUU untuk dibahas yang diajukan oleh Presiden dan DPD untuk RUU berkaitan dengan otonomi daerah, hubungan pusat dan daerah, pembentukan dan pemekaran serta penggabungan daerah, pengelolaan sumber daya alam dan sumber daya ekonomi lainnya, serta perimbangan keuangan pusat dan daerah, tidak diatur untuk disampaikan kepada DPD. RUU dari DPR berkaitan dengan otonomi daerah, hubungan pusat dan daerah, pembentukan dan pemekaran serta penggabungan daerah, pengelolaan sumber daya alam dan sumber daya ekonomi lainnya, serta perimbangan keuangan pusat dan daerah tidak diatur untuk disampaikan kepada DPD. Akibatnya, kewenangan DPD terkait hal ini tidak ada atau dikurangi.

Ketentuan Pasal 170 ayat $(5)^{36}$ UU MD3 mendelegitimasi kewenangan DPD dalam pembahasan RUU karena bersifat under estimate keberadaan DPD. Di dalam putusan MK Nomor 92/PUU-X/2012 sebenarnya ketentuan Pasal 170 ayat $(5)^{37}$ dinyatakan bertentangan dengan UUD NRI 1945. Dengan adanya ketentuan tersebut, DPD dirugikan kewenangannya karena tidak diberi kesempatan untuk menyampaikan pernyataan akhir. Padahal pernyataan akhir itu penting, sebagai bentuk akuntabilitas publik dalam suatu pembahasan RUU, bukan dalam konteks persetujuan atau penolakan RUU.

Begitupun dengan Pasal 249 hurufb UU MD3, ketentuan ini mengaburkan pihak yang menjadi subjek RUU sehingga mengurangi kewenangan DPD dalam proses RUU. Dibandingkan dengan 
Pasal 224 ayat (1) huruf b dan c UU 27/2009, ${ }^{38}$ ketentuannya lebih jelas.

\section{c. Dikuranginya Kewenangan DPD Dalam Kedudukannya Sebagai Lembaga Perwakilan Daerah}

Kewenangan DPD sebagai lembaga perwakilan daerah sebagaimana dimaksud dalam BAB VIIA DEWAN PERWAKILAN DAERAH Pasal 22C dan Pasal 22D UUD NRI 1945 direduksi/dirugikan oleh ketentuan-ketentuan dalam UU MD3yaitu Pasal 72, Pasal 174 ayat (1), Pasal 174 ayat (4), Pasal 174 ayat (5), Pasal 250 ayat (1), Pasal 245 ayat (1), Pasal 252 ayat (4), Pasal 281, Pasal 305, dan Pasal 307 ayat (2).

Pasal 72 UU MD3 ${ }^{39}$ belum mengakomodasi tugas DPR untukmembahas dan menindaklanjuti hasil pengawasan yang dilakukan oleh DPD. Selain itu juga belum memasukkan tugas DPR membahas dan menindaklanjuti pertimbangan DPD terhadap calon anggota BPK. Tidak diaturnya kedua hal tersebut, merugikan kewenangan DPD sebagaimana yang telah dijamin UUD NRI 1945.

Ketentuan Pasal 174 ayat $(1)^{40}$ dan Pasal 174 ayat $(4)^{41}$ UU MD3membatasi kewenangan DPD untuk memberikan pertimbangan mengenai RUU APBN dan RUU yang berkaitan dengan pajak, pendidikan, dan agama karena berupa pertimbangan tertulis. Pertimbangan DPD harusnya sudah masuk dalam tahap pembahasan antara DPR dan Presiden. Frasa pertimbangan tentu tidak hanya sekedar pertimbangan secara tertulis, melainkan juga harus disampaikan didalam tahap penjelasan. Apabila hanya tertulis dan dilakukan sebelum memasuki tahap pembahasan antara DPR dan Presiden. Penyampaian secara tertulis hanya bermakna pemenuhan syarat formalitas belaka, maka proses semacam ini jelas mengelabui kewenangan dan tugas DPD sebagaimana amanat Pasal 22D ayat (2) UUD NRI 1945.

Pasal 174 ayat (5) UU MD3 merugikan DPD karena kedudukan DPD masih tetap dianggap

38 Indonesia, Undang-Undang Nomor 17 Tahun 2014 tentang MD3, Pasal 224 ayat (1) huruf b "DPD ikut serta membahas bersam DPR dan Presiden RUU yang berkaitan dengan hal sebagaimana dimaksud hurufa". Sedangkan huruf c "DPD ikut membahas bersama DPR dan Presiden RUU yang diajukan oleh Presiden dan DPR, yang berkaitan dengan hal sebagaimana dimaksud dalam hurufa".

39 Indonesia, Undang-Undang Nomor 17 Tahun 2014 tentang MD3, Pasal 72 "DPR bertugas: a. menyusun, membahas, menetapkan, dan menyebarluaskan Program Legislasi Nasional; b. menyusun, membahas, dan menyebarluaskan rancangan undang-undang; c. menerima rancangan undang-undang yang diajukan oleh DPD berkaitan dengan otonomi daerah, hubungan pusat dan daerah, pembentukan dan pemekaran serta penggabungan daerah, pengelolaan sumber daya alam dan sumber daya ekonomi lainnya, serta yang berkaitan dengan perimbangan keuangan pusat dan daerah; d. melakukan pengawasan terhadap pelaksanaan undang-undang, APBN, dan kebijakan pemerintah; e. membahas dan menindaklanjuti hasil pemeriksaan atas pengelolaan dan tanggung jawab keuangan negara yang disampaikan oleh BPK; $f$. memberikan persetujuan terhadap pemindahtanganan aset negara yang menjadi kewenangannya berdasarkan ketentuan peraturan perundang-undangan dan terhadap perjanjian yang berakibat luas dan mendasar bagi kehidupan rakyat yang terkait dengan beban keuangan negara; g. menyerap, menghimpun, menampung, dan menindaklanjuti aspirasi masyarakat; dan h. melaksanakan tugas lain yang diatur dalam undang-undang".

40 Indonesia, Undang-Undang Nomor 17 Tahun 2014 tentang MD3, Pasal 174 ayat (1) "DPR menerima dan menindaklanjuti pertimbangan tertulis mengenai RUU yang berkaitan dengan pajak, pendidikan, dan agama yang disampaikan oleh DPD sebelum memasuki tahap pembahasan antara DPR dan Presiden".

Indonesia, Undang-Undang Nomor 17 Tahun 2014 tentang MD3, Pasal 174 ayat (4) "Pertimbangan DPD sebagaimana dimaksud pada ayat (2) dan ayat (3) disampaikan secara tertulis melalui pimpinan DPR paling lama 30 (tiga puluh) hari sejak diterimanya surat pimpinan DPR, kecuali RUU tentang APBN dsampaikan paling lambat 14 (empat belas) hari sebelum diambil persetujuan bersama antara DPR dan Presiden". 
subordinasi dari DPR, karena pertimbangan yang diberikan oleh DPD tidak dalam forum tripatrit kelembagaan, melainkan di dalam forum DPR melalui alat kelengkapan DPR. ${ }^{42}$

Begitupun dengan ketentuan Pasal 224 ayat (5) dan Pasal 245 ayat (1) UU MD3, kedua ketentuan tersebut mendelegitimasi kewenangan DPD dalam kedudukan sebagai lembagaperwakilandaerah karena menciptakan ketidakseimbangan kedudukan antar lembaga perwakilan. Dengan adanya persetujuan tertulis dari mahkamah kehormatan dewan dalam hal pemanggilan dan permintaan keterangan untuk penyidikan terhadap anggota DPR yang diduga melakukan tindak pidana sedangkan bagi anggota DPD yang berdasarkan Pasal 289 ayat (1) UU 27/2009 harus mendapat persetujuan dari Presiden, dihapus, maka terjadi perlakuan yang diskriminatif antar lembaga perwakilan. Demikian pula ketika anggota DPD menjadi anggota MPR, dengan dihapuskannya Pasal 66 UU 27/2009 berpengaruh kepada penyidikan terhadap anggota MPR yang berasal dari DPD. Pengaruhnya adalah pemanggilan dan permintaan keterangan untuk penyidikan terhadap anggota MPR yang berasal dari anggota DPD yang disangka melakukan tindak pidana tanpa melalui persetujuan tertulis dari Presiden. Sedangkan pemanggilan dan permintaan keterangan untuk penyidikan terhadap anggota MPR yang berasal dari DPR yang disangka melakukan tindak pidana dilakukan dengan persetujuan tertulis dari Mahkamah Kehormatan DPR. Dengan demikian, terjadi diskriminasi antar anggota lembaga perwakilan.

Ketentuan Pasal 250 ayat (1)UUMD3 berbeda sifat kewenangan penyusunan anggaran bagi MPR dan DPR sebagaimana diatur Pasal 6 ayat (1) bahwa MPR memiliki kemandirian dalam menyusun anggaran dan Pasal 75 ayat (1) DPR memiliki kemandirian. ${ }^{43}$ Berbeda dengan Pasal 250 ayat (1) UU MD3yang mengatur DPD tidak ada pengaturan kemandirian DPD dalam menyusun anggaran. Ketentuan ini juga merugikan DPD karena bersifat diskriminatif.

Dalam Pasal 252 ayat (4) UU MD3, DPD mempunyai kantor di ibukota provinsi daerah pemilihannya. ${ }^{44}$ Namun DPD dirugikan karena tidak ada kepastian waktu (time frame) pembangunan kantor dimaksud. Hal ini berbeda dengan ketentuan Pasal 402 UU 27/2009 yang telah dihapus dimana penyediaan kantor DPD disetiap ibukota provinsi dilakukan secara bertahap oleh pemerintah paling lama 2 (dua) tahun sejak Undang-Undang diundangkan.

Untuk Pasal $281^{45}$ UU MD3, mereduksi kewenangan dalam memberikan pertimbangan 
RUU sebagaimana amanat UUD NRI 1945 karena pertimbangannya disampaikan kepada pimpinan DPR. Pentingnya kepada DPR bukan kepada pimpinan DPR karena DPD dalam mengajukannya tidak ditentukan oleh undangundang tersebut oleh pimpinan DPD.

Pasal $305^{46}$ UU MD3ini juga bersifat diskriminatif sehingga merugikan DPD karena hanya ditujukan kepada anggota DPD, sedangkan ketentuan serupa untuk DPR telah dihapus. Begitupun dalam hal terkait dengan ketentuan pergantian antar waktu dalam Pasal 307 ayat $(2)^{47}$ UU MD3huruf d hanya ditujukan kepada anggota DPD. Ketentuan serupa untuk anggota DPR telah dihapus. Bahwa kewenangan konstitusional DPD tersebut telah sangat merugikan dengan berlakunya UU MD3. Kerugikan tersebut bersifat spesifik dan potensial berdasarkan penalaran yang wajar dipastikan akan terjadi serta mempunyai hubungan kausal dengan berlakunya pasalpasal dalam undang-undang tersebut.

\section{Penutup}

Politik hukum legislasi pasca Putusan MK Nomor 92/PUU-X/2012 ialah dengan melakukan revisi UU 27/2009, UU P3, yang berkaitan dengan 5 (lima) hal substansial sebagaimana yang terdapat dalam Putusan MK Nomor 92/ PUU-X/2012, yaitu: a) dalam mengajukan Rancangan Undang-Undang (RUU) yang berkaitan dengan daerah, DPD setara dengan
DPR dan Presiden; b) Hak/kewenangan DPD sama dengan DPR dan Presiden dalam membahas Rancangan Undang-Undang tertentu; c) DPD ikut membahas RUU, tetapi tidak ikut memberi persetujuan terhadap RUU menjadi UU; d) DPD ikut menyusun Program Legislasi Nasional; dan e) DPD memberikan pertimbangan tanpa ikut serta dalam pembahasan RUU. Dalam hal ini, DPR dan Presiden wajib untuk meminta pertimbangan DPD atas RUU APBN.

Hal tersebut telah dilaksanakan oleh pembentuk undang-undang dengan dikeluarkannya UU MD3. Akan tetapi ketentuanketentuan UU MD3 tersebut telah merugikan hak konstitusional DPD di bidang legislasi sebagaimana telah dijamin UUD NRI 1945. $\mathrm{Hal}$ ini menunjukan bahwa pembentukan UU MD3 nyata-nyata tidak menghormati putusan MK yang diberi mandat UUD NRI 1945 sebagai lembaga penafsir dan penjaga konstitusi, tidak menghormati, mematuhi, dan melaksanakan putusan MK ini menunjukkan ketidakpatuhan terhadap putusan lembaga negara yang telah ditunjuk konstitusi untuk mengawal kemurnian pelaksanaan konstitusi.

Terlepas dari pelanggaran yangsecarasengaja dilakukan pembuat UU sebagaimana dimaksud di atas, maka terdapat 2 (dua) formalitas yang dilanggar dalam proses pembuatan UU MD3. Pertama, keikutsertaan DPD untuk mengajukan RUU dan membahasa serta menyetujui RUU MD3 yang menyangkut kedudukan, susunan dan kewenangan DPD. Sebagaimana putusan MK

\footnotetext{
46 Indonesia, Undang-Undang Nomor 17 Tahun 2014 tentang MD3, Pasal 305 "Setiap orang, kelompok, atau organisasi dapat mengajukan pengaduan kepada Badan Kehormatan DPD dalam hal memiliki bukti yang cukup bahwa terdapat anggota DPD yang tidak melaksanakan salah satu kewajiban atau lebih sebagaimana dimaksud dalam Pasal 262 dan/atau melanggar ketentuan larangan sebagaimana dimaksud dalam Pasal 302".

47 Indonesia, Undang-Undang Nomor 17 Tahun 2014 tentang MD3, Pasal 307 ayat (2) huruf d "Tidak menghadiri sidang parpurna dan/atau rapat alat kelengkapan DPD yang menjadi tugas dan kewajibannya sebanyak 6 (enam) kali berturut-turut tanpa alasan yang sah".
} 
Nomor 92/PUU-X/2012 yang telah menafsirkan Pasal 22D ayat (1) dan ayat (2) UUD NRI 1945 memberi kedudukan DPD yang setara dengan Presiden dan DPR, maka pengesampingan DPD dalam proses pengajuan dan pembahasan UU MD3 merupakan pelanggaran terhadap UUD NRI 1945. Setiap pembahasan yang tidak mengikutsertakan DPD dalam pembuatan undang-undang yang menyangkut dirinya, merupakan pembentukan undang-undang yang tidak memenuhi ketentuan berdasarkan UUD (cacat prosedural), akan berakibat bahwa undang-undang demikian tidak mempunyai kekuatan hukum mengikat secara keseluruhan. Kedua, perintah konstitusi untuk mengatur susunan dan kedudukan DPD "dengan UndangUndang", memberi indikasi bahwa undangundang dimaksud akan dibuat secara tersendiri dan tidak rada dalam satu undang-undang yang sama dengan MPR, DPR, DPRD.

Pembentuk Undang-Undang dalam hal ini DPR dan Presiden harus segera melakukan perubahan UU Nomor 12 Tahun 2011 tentang Pembentukan Peraturan Perundangundangan dengan berpijak pada ramburambu konstitusional Putusan MK Nomor 92/ PUU-X/2012.

\section{DAFTAR PUSTAKA}

\section{Buku}

Arifin, Firmansyah, dkk, Lembaga Negara dan Sengketa Kewenangan Antar Lembaga Negara, (Jakarta: Konsorsium Reformasi Hukum Nasional (KRHN) bekerjasama dengan MK Republik Indonesia (MKRI), 2005)

Asshiddiqie, Jimly, Konstitusi Bernegara: Praksis Kenegaraan Bermartabat dan Demokratis, (Malang: Setara Press, 2015)

Asshiddiqie, Jimly, Konstitusi dan Konstitualisme Indonesia, Cetakan Kedua, (Jakarta: Konpress, 2006)
Asshiddiqie, Jimly, Pengantar Ilmu Hukum Tata Negara, Jilid II, (Jakarta: Sekretariat Jendral dan Kepaniteraan MKRI, 2006)

Asshiddiqie, Jimly, Pokok-Pokok Hukum Tata Negara Indonesia Pasca Reformasi (Jakarta: Bhuana IImu Populer, 2007)

Dewan Perwakilan Daerah, Konstitusi Republik Indonesia Menuju Perubahan Kelima, Cetakan Ketiga, (Jakarta: Grafitribudi Utami, 2009)

Dicey, A.V., Inroduction to the study of the law of the constitution, Tenth Edition (London: Macmillan Education LTD, 1959)

Fajar, Mukti, dan Yulianto Achmad, Dualisme Penelitian Hukum Normatif dan Empiris (Yogyakarta: Pustaka Pelajar, 2010)

Ibrahim, Johny, Teori dan Metodologi Penelitian Hukum Normatif (Malang: Bayumedia, 2005).

Kelompok DPD di MPR RI, Eksistensi DPD RI 20092013 Untuk Daerah dan NKRI, Cetakan Kedua, (Jakarta: Kelompok DPD di MPR RI, 2013)

Latif, Abdul, Fungsi MK dalam Mewujudkan Negara Hukum Demokrasi (Yogyakarta: Total Media, 2007)

Mahfud MD, Moh., Dasar dan Struktur Kenegaraan Indonesia, Cetakan Kedua, (Jakarta: Rineka Cipta, 2001)

Mahfud MD, Moh., Politik Hukum di Indonesia (Jakarta: Rajawali Press, 2011)

Sartori, Giovanni, Comparative Constitutional Engineering: An Inquiry into Structures, Incentives and Outcomes (New York: New York University Press, 1997)

Sekretariat Jenderal DPD RI, Profil Dewan Perwakilan Daerah Republik Indonesia Tahun Sidang 20142015, (Jakarta: Sekretariat Jenderal DPD RI, 2015)

Sherlock, Stephen, Indonesia's Regional Representative Assembly: Democracy, Representation and the Regions, (Australia: Centre for Democratic Institutions Research School of Social Sciences, Australian National University, 2005)

Soekanto, Soerjono, Pengantar Penelitian Hukum, (Jakarta: UI Press, 1986)

Tutik, Titik Triwulan, Kontruksi Hukum Tata Negara Indonesia Pasca Amandemen UUD NRI 1945, Cetakan Kedua (Jakarta: Raja Grafindo Persada, 2006) 


\section{Internet}

DPD Sambut Baik Putusan MK soal Kewenangan Legislasi", Rabu, 23 Maret 2013. http://nasional. kompas.com/read/2013/03/27/18574762/DPD. Sambut.Baik.Putusan.MK.soal.Kewenangan. Legislasi. (Diakses 22 Maret 2014)

\section{Peraturan}

Undang-Undang Dasar Negara Republik Indonesia Tahun 1945

Undang-Undang Nomor 27 Tahun 2009 tentang MPR, DPD, dan DPRD

Undang-Undang Nomor 12 Tahun 2011 tentang Pembentukan Peraturan Perundang-undangan

Undang-Undang Nomor 17 Tahun 2014 tentang Perubahan Atas Undang-Undang Nomor 27 Tahun 2009 tentang MPR, DPD, dan DPRD

Putusan Mahkamah Konstitusi Nomor 92/ PUU-X/2012. 